\title{
PENGARUH BIMBINGAN DAN KONSELING ISLAM DALAM MENENTUKAN MINAT DAN BAKAT ANAK DI SEKOLAH DASAR
}

\author{
Nilam Cahaya, Adinda Latifah, Fikri Firmansyah, Riski Maulana Anggita \\ Institut Agama Islam Negeri Syaikh Abdurrahman Siddik Bangka Belitung \\ Email: Smartphoneadvan47@gmail.com, adindakoya08@gmail.com
}

\begin{abstract}
Abstrak
Penelitian merupakan penelitian kualitatif, yang berkepentingan untuk menggambarkan konsep pengembangan bakat dan minat di UPTD SD N 04 Mendo Barat, tanggal 03 Desember 2021. Bakat merupakan suatu potensi lahiriyah yang ada pada diri - sendiri yang masih dipengaruhi gen dari orang tua dan masih perlu untuk dikembangkan. Minat merupakan dorongan yang berasal dari dalam diri sendiri dan menimbulkan sebuah ketertarikan pada sesuatu yang biasanya bersifat menyenangkan. minat harus ada keyakinan niat dan kemampuan diri sendiri karena akan dapat tersalurkan dengan maksimal terhadap hal yang disenanginya. Penelitian ini mengambil siswa kelas 6 sebagai responden, yang terdiri dari 23 siswa. Metode yang di lakukan adalah pengumpulan data dengan menggunakan teknik observasi dan dokumentasi. Teknik observasi dilaksanakan dengan beraangota 4 orang dengan membagikan angket kepada seluruh siswa. Analisis data bersifat deskriptif. Hasil penelitian menunjukkan perkembangan minat dan bakat siswa pada anak sekolah dasar di UPTD SD N 04 Mendo Barat siswa banyak yang memiliki bakat dan minat dalam cabang olahraga badminton dan sepak bola. Sedangkan para siswi lebih banyak yang memiliki bakat dan minat dalam bidang seni seperti sholawat dan lain -lain. Jadi dapat dilihat bahwa anak kelas 6 di UPTD SD N 04 Mendo Barat sudah bisa memilih mana bakat dan minat yang ingin mereka pelajari dan mereka tekuni.
\end{abstract}

Kata kunci : bakat, minat, perkembangan

\section{Abstract}

This research is qualitative research, which has an interest in describing the concept of developing talent and interest at UPTD SD N 04 Mendo Barat, December 03, 2021. Talent is an outward potential that exists in oneself which is still influenced by genes from parents and still needs to be developed. developed. Interest is an impulse that comes from within oneself and causes an interest in something that is usually pleasant. Interest must have confidence in one's own intentions and abilities because it will be able to be channeled to the maximum for the things he likes. This study took 6th grade students as respondents, which consisted of 23 students. The method used is data collection using observation and documentation techniques. The observation technique was carried out with 4 people by distributing questionnaires to all students. Data analysis is descriptive. The results showed the development of students' interests and talents in elementary school children at UPTD SD N 04 Mendo Barat, many students had talents and interests in badminton and soccer. While more students who have 
talent and interest in the arts such as prayer and others. So it can be seen that the 6th graders at UPTD SD N 04 Mendo Barat are able to choose which talents and interests they want to learn and pursue.

Keywords: Talent, Interest, Development

Diserahkan: 03-01-2022Ｄiterima: 25-01-2022Ｄiterbitkan: 20-02-2022

\section{Pendahuluan}

Setiap anak memiliki potensi bakat dan minatnya masing-masing. Sedangkan potensi yang dimiliki anak dapat berkembang sesuai dengan kemampuan pada diri masingmasing potensi bakat yang dimilikinya. Kemampuan potensi yang dimiliki anak merupakan yang sudah melekat pada diri anak tersebut pada bawaanya dari ia lahir, namun hal itu mengetahui kemampuan bakat anak dengan cara mengali dan mencari jati diri anak tersebut (Hikmawan, 2017).

Maka dari itu bakat harus dikembangkan dan di asah agar bakat tersebut dapat terwujud. Bakat memiliki barbagai macam bidang seperti seni, olahraga, akademik, dan lainnya. Tapi banyak orang yang tidak mengetahui apa bakat mereka dikarenakan kurangnya kesadaran akan bakat yang dimilikinya. selain itu, penyebab lainnya seperti tidak adanya fasilitas yang memadaai untuk mendukung bakat yang dimilikinya sehingga bakatnya tidak dapat tersalurkan dengan maksimal (Ekawarna, 2018).

Bakat pasti selalu terikat dengan yang namanya minat. Minat sendiri merupakan dorongan dari niat yang berasal dari dalam diri kita sendiri dan menimbulkan sebuah ketertarikan pada apa yang disukai dan apa yang bersifat menyenangkan. minat berpengaruh terhadap niat pada diri anak masing- masing dalam mengali dan mendalami minat dan bakat anak tersebut agar harus berjalan dengan baik agar dapat maksimal terhadap hal yang menjadi masa depan anak. Minat sangat penting untuk mendorong anak agar lebih selektif dan ekspresif dalam menunjukkan kemampuan yang dimiliki anak agar menimbulkan rasa puas dan lebih rasa pecaya diri pada anak (Rahmat, 2021).

Seperti yang disampaikan di atas bakat dan minat sangatlah penting. Oleh karena itu bakat dan minat harus diperkenalkan ketika kepada anak yang ber usia dini dan selalu diperhatikan pada setiap perkembangnya agar individu dapat mengetahui apa bakat dan minat yang kuasainya sehingga individu dapat dalam proses meraih prestasi dari bakat dan minat yang dimilikinya (Santrock, 2021).

\section{Tinjauan Pustaka}

\section{Pengertian Bakat}

Bakat, kemampuan akan terlihat sejak lahir sangat perlu dilatih dan dikembangkan kembali maka peran orang orang tua sangat di butuhkan dalam proses tersebut. Pada dasarnya bakat setiap orang memiliki bidangnya masing-masing. Dalam hal ini, setiap individu memiliki potensi alamiah yang berbeda sejak mereka lahir. Ada individu yang memiliki potensi dalam bidang kesenian, olahraga, akademik dan bakat lainnya. Potensi yang dimiliki masing-masing individu tersebut masih perlu dikembangkan dan dilatih 
untuk mencapai prestasi sesuai dengan bakat yang dimiliki setiap anak. misalnya seseorang yang memiliki bakat dalam bermusik maka dalami dan terus gali, sedangkan seseorang anak berbakat dalam olahraga, setiap anak akan berbeda bidang karena sesuai dari kemampuan dan potesi dimiliki anak tersebut. Maka dari itu setiap anak harus mengetahui bakat yang apa yang dimilikinya dalam proses latihan, pengetahuan, dan pengalaman agar bakat dapat berkembang dengan baik dan maksimal (Irawan, 2011).

\section{Pengertian Minat}

Minat adalah kekuatan pendorong terhadap kemampuan anak dan potisi yang dimiliki anak dalam mengembangkan dan mendalami. Pada dasarnya minat memiliki peran penting dalam kehidupan tiap anak dan sangat berpengaruh terhadap perkembangan dan pengembangan setiap anak. Minat sumber motivasi yang kuat untuk individu yang memiliki minat terhadap sesuatu baik itu dalam bidang kesenian, olahraga, akademik, dan bidang lainnya pasti ia akan bersungguh-sungguh melakukannya karena memiliki minat yang kuat untuk mencapai tujuan yang diinginkannya. Misalnya seseorang memiliki minat yang kuat dalam dalam menyanyi, maka ia akan terus berlatih dengan sangat bersungguh-sungguh agar tujuan yang diinginkannya tercapai. Jadi dari contoh diatas dapat dilihat bahwa minat juga sangat berpengaruh pada bakat, tanpa minat yang kuat bakat seseorang tidak akan berkembang (Sutrisno, 2020).

\section{Macam- Macam Bakat}

Bakat dibagi menjadi dua bagian yaitu bakat umum dan bakat khusus. Bakat umum adalah bidang yang banyak diminati dan mudah dilatih dan dipelajari dalam proses mengembngkan bakat setiap anak (Izzaty, 2017). Sedangkan bakat khusus adalah kemampuan dan pontensi yang memiliki anak yang tidak mudah dilakukan anak seumurnya dan tidak mudah untuk mempelajari dan di dalami dalam mengembangkan bakat anak. Bakat khusus antara lain:

\section{a. Bakat verbal}

Bakat verbal adalah kemampuan anak dalam mengacu pada ungkapan dan kata kata Contohnya yaitu bakat dalam berdiplomatis

b. Bakat numerikal

Bakat numerikal adalah bakat lebih mengacu pada angka-angka. Contohnya adalah seorang akuntan.

c. Bakat skolastik

Bakat skolastik adalah kombinasi kata-kata dan angka-angka yang mengacu pada potensi anak. Pengaruh bakat skolastik adalah dapat penalaran berfikir dalam pola sebab akibat, mengurutkan, memahami pola numerik, dan pandangan hidupnya bersifat rasional. Bakat ini dimiliki oleh seorang ilmuan dan progammer.

d. Bakat abstak

Bakat abstak adalah bakat yang tidak mengacu pada angka ataupun kata melainkan mengacu dalam pola, rancangan, diagram, ukuran-ukuran, dan posisi-posisinya.

e. Bakat mekanik

Bakat mekanik adalah bakat yang dimiliki anak mengacu pada prinsip-prinsip umum yaitu ipa, tata kerja mesin, perkakas dan lainnya 


\section{f. Bakat relasi ruang}

Bakat relasi ruang adalah bakat yang dimiliki anak pada proses mengamati dan menceritakan, ada pola dalam bakat relasi ruang yaitu 2 dimensi dan berfikir dalam bakat relasi 3 dimensi serta memiliki kemampuan yang tajam dan dapat melukis atau membuat sketsa dengan jelas. Bakat ini biasanya dimiliki oleh para arsitek.

g. Bakat ketelitian klerikal

Bakat ketelitian klerikal adalah bakat yang dimiliki anak pada tulis menulis dan ramu meramu untuk laboratorium.

h. Bakat bahasa

Bakat bahasa adalah kemampuan yang mengacu pada penalaran dan mengalisis bahasa.

Berdasarkan tripologi Buckingham terdapat 7 bakat dasar yang terkuat dalam bakat yang diminat anak (Patmonodewo, 2000). Berikut ini bakat yang ada dalam diri manusia yaitu sebagai berikut:

a. Achiever (Berprestasi)

Archiver ini adalah kemampuan yang dimiliki seseorang yang selalu mendorongnya untuk terus mendapatkan prestasi dengan memasang target setinggi mungkin agar bisa mendapatkan apa yang diinginkan.

b. Activator (Senang Mengaktifkan)

Activator ini adalah kemampuan yang menyukai memulai hal-hal yang konkrit, tidak sabar untuk memulai berbuat sesuatu dan berani menggambil resiko meskipun belum mendapat banyak informasi karena menurutnya kesalahan adalah hal yang wajar dala proses pembelajaran

c. Adaptability (Menyesuaikan Diri)

Adaptability ini adalah kemampuan diri seseorang yang mudah untuk menyesuaikan diri dalam suatu keadaan yang tidak disangka tanpa merasakan kecewa karena baginya perubahan itu teman bukanlah musuh

d. Analytical (Senang Menganalisa)

Analytical ini adalah kemampuan seseorang yang terbiasa berbicara dalam bahasa data, selalu berfikir sebab dan akibat, dan setiap berita yang didengarnya harus disertakan bukti yang jelas.

e. Command (Naluri Untuk Mengomando)

Command ini adalah kemampuan seseorang yang selalu ingin melakukan pertanggung jawaban seperti mengambil alih keadaan dengan menggunakan perintah hingga dirinya merasa puas.

f. Communication (Komunikasi)

Communication ini adalah kemampuan seseorang yang sangat gemar berkomunikasi, dan mudah beradapsi pada lingkungan dalam berkomunikasi berbicara didepan umum baik lisan maupun tulisan, dan dapat mengangkat topik yang menarik dengan ciri khasnya dalam berbicara.

g. Empathy (Bisa Merasakan Perasaan Orang Lain) 
Empaty ini adalah kemampuan seseorang yang bisa mengerti perasaan orang lain, selalu berfikir bagaimana dia jika diposisi orang tersebut.

\section{Macam-Macam Minat}

Macam-macam minat ada empat yaitu, minat primitif, minat kultural, minat subyektif dan minat obyektif (Sitepu, 2019). Jenis-jenis minat tersebut dijelaskan sebagai berikut:

a. Minat Primitif

Minat primitif merupakan manusia yang membutuhkan kebahagiaan hidup dan kebebasan aktivitas dalam minat sangat berpengaruh terhadap biologis yang timbul dari manusia.

b. Minat Kultural

Minat kultural merupakan kekuasaan, kekayaan, bahasa simbol, harga diri atau sosial dalam proses belajar karena yang lebih tinggi akan lebih di hargai.

c. Minat Subyektif

Minat subyektif merupakan pengalaman- pengalaman proses yang dilalui dapat duhitung bersifat menyenangkan.

d. Minat Obyektif

Minat obyektif merupakan kegiatan dilingkungan gotong royong menerima reaksi positif dalam kegiatan dilingkungannya.

\section{Cara mengenali bakat dan minat}

Bakat merupakan suatu kemampuan yang dimiliki dalam diri anak, maksudnya bakat itu masih berupa kemampuan perilaku yang sudah nampak dan bisa diamati. Misalnya sepeda yang mempunyai potensi untuk melaju cepat apabila sepeda tersebut mendapatkan kincangan yang cepat. Oleh karena itu, bakat perlu mendapatkan didikan dan latihan agar dapat menciptakan sebuah prestasi yang membanggakan (Rudyanto, 2016). Ada 2 cara yang bisa dilakukan untuk mengenali bakat yaitu sebagai berikut:

Melakukan tes bakat yang diselenggarakan oleh tenaga ahli yang berwenang. Melalui pengalaman, dengan cara melihat fortofolio seseorang dan apabila dari sekolah dasar hingga ia menyelesaikan sekolahnya ia unggul dalam bidang yang tertulis di fortofolionya, maka orang tersebut memiliki bakat dalam bidang yang tertulis di portofolionya. Misalnya seseorang tersebut memiliki prestasi dalam bidang bahasa inggris, maka orang tersebut unggul dalam bidang bahasa inggris.

\section{Metode Penelitian}

Melakukan penelitian menggunakan pendekatan kualitatif, hasil prosedur penelitian menghasilkan data deskriptif berupa kata-kata tertulis atau lisan (Sugiyono, 2012). Metode yang dilakukan berlandaskan pada filsafat postpositivisme digunakan untuk meneliti kondisi objek yang alamiah (sebagai lawannya adalah eksperimen) dimana peneliti ialah sebagai instrument kunci, teknik pengumpulan data dilakukan secara triangulasi (gabungan), analisis data bersifat induktifkualitatif, dan hasil penelitian kualitatif lebih menekankan makna dari pada generalisasi. Jenis penelitian adalah studi 
kasus mempelajari sebuah komunitas secara intensif mengenai upaya pengembangan bakat dan minat siswa di UPTD SD N 04 Mendo Barat.

\section{Hasil dan Pembahasan}

\section{Deskripsi Data Penelitian}

Penetian ini dimaksudkan untuk membahas ada tidaknya hubungan yang signifikan antara bimbingan konseling dengan bakat dan minat pada siswa kelas 6 di Uptd SD Negeri 04 Mendo Barat. Data yang diperoleh dari instrument penelitian berupa pembagian angket dan observasi yang disampaikan peneliti ke objek penelitian dengan membagikan angket dan observasi kepada seluruh siswa kelas 6 di ruangan kelas.Adapun hasil penelitian yang diperoleh melalui pembagian angket yaitu sebagai berikut:

\section{a. Bakat dan minat}

Dari angket yang telah kami bagikan kepada seluruh siswa, untuk siswa laki-laki rata-rata memiliki bakat dan minat pada cabang olahraga yaitu sepak bola, badminton, dan atletik. Untuk siswi perempuan rata-rata memiliki bakat dan minat pada cabang seni yaitu sholawat, melukis, dan tilawah.

b. Bimbingan dan konseling

Pada angket yang kami bagikan tercantum sebuah pertanyaan mengenai permasalahan yang dihadapi dalam perkembangan bakat dan minat siswa. Seperti yang dapat diketahui ada beberapa faktor yang menghambat perkembangan bakat dan minat salah satunya yaitu tidak adanya dukungan dari orang tua yang menyebabkan anak kehilangan semangat dan parahnya anak tidak bisa percaya diri dengan kemampuan yang dimilikinya. Dari hasil angket yang telah kami bagikan keseluruhan anak kelas 6 di Uptd SD Negeri 04 Mendo Barat tidak memiliki masalah terhadap dukungan orang tua dalam perkembangan bakat dan minatnya.

\section{Pengaruh yang Signifikan Antara Bimbingan dan Konseling dengan Bakat dan Minat Siswa}

perkembangan bakat dan minat pada anak diutamakan adalah adanya rasa percaya diri serta optimis dalam mencapai kesuksesan pada bakat dan minat yang dimiliki anak. Jika anak tidak memiliki rasa percaya diri dan tidak optimis dalam mencapai kesuksesan pada bakat dan minatnya, akan sulit bagi siswa tersebut mencapai kesuksesan itu dan iti akan berpengaruh pada kesehatan mental siswa dan perlu untuk melakukan konseling agar siswa dapat berubah dan mencapai kesuksesan pada bakat dan minatnya. Untuk itu pentingnya bimbingan dan konseling dalam perkembangan bakat dan minat pada siswa agar dapat emncapai kesuksesan pada bakt dan minat yanf telah mereka miliki.

\section{Kesimpulan}

Dari penelitian Bimbingan Dan Konseling Islam Dalam Menentukan Minat dan Bakat Anak Di Sekolah Dasar (Pada Siswa Kelas 6 Di Uptd Sd Negeri 4 Mendo Barat). yang dilaksanakan pada jumat 03 desember 2021. Minat adalah proses kegiatan yang diminati anak yang terus- menurus harus dikembangkan dalam mengejar bakat.Bakat menurut Kamus Istilah Bimbingan dan penyuluhan adalah suatu kualitas yang dimiliki 
oleh anak dalam berkembang pada masa yang akan datang. Dapat disimpulkan bahwa minat bakat siswa dapat dilihat para siswa banyak yang memiliki bakat dan minat dalam cabang olahraga badminton dan sepak bola. Sedangkan para siswinya lebih banyak minati dalam bidang seni yaitu sholawat. Jadi dapat dilihat bahwa anak kelas 6 di UPTD SD N 04 Mendo Barat sudah bisa memilih mana bakat dan minat yang ingin mereka pelajari dan tekuni. Hasil tersebut ada dukungan terhadap keluarga maupun sekolah, guru dan siswa yang mengembangkan minat dan bakat untuk ditekunin siswa 


\section{BIBLIOGRAFI}

Ekawarna, E. (2018). Manajemen Konflik dan Stres. Bumi Aksara. Google Scholar

Hikmawan, F. (2017). Perspektif filsafat pendidikan terhadap psikologi pendidikan humanistik. Jurnal Sains Psikologi, 6(1), 31-36. Google Scholar

Irawan, S. (2011). Pengembangan bakat kepemimpinan siswa melalui kegiatan OSIS di SMA N 4 Depok. Google Scholar

Izzaty, R. E. (2017). Perilaku anak prasekolah. Elex Media Komputindo. Google Scholar

Patmonodewo, S. (2000). Pendidikan anak prasekolah. Rineka Cipta bekerjasama dengan Departemen Pendidikan \& Kebudayaan. Google Scholar

Rahmat, P. S. (2021). Psikologi pendidikan. Bumi Aksara. Google Scholar

Rudyanto, H. E. (2016). Pengembangan kreativitas siswa sekolah dasar melalui pembelajaran matematika open-ended. Premiere Educandum: Jurnal Pendidikan Dasar Dan Pembelajaran, 3(02). Google Scholar

Santrock, J. W. (2021). Psikologi pendidikan. Google Scholar

Sitepu, A. S. M. B. (2019). Pengembangan Kreativitas Siswa. Guepedia. Google Scholar Sugiyono. (2012). Metode Penelitian Kuantitatif, Kualitatif, dan R\&D (22nd ed.). Alfabeta CV. Google Scholar

Sutrisno, M. (2020). Meningkatkan Minat Dan Hasil Belajar Tik Materi Topologi Jaringan Dengan Media Pembelajaran. Ahlimedia Book. Google Scholar

First publication right:

Jurnal Syntax Fusion: Jurnal Nasional Indonesia

This article is licensed under:

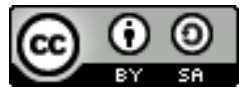

